\title{
Commentary \\ Breast cancer chemoprevention: beyond tamoxifen
}

\section{Carol J Fabian}

University of Kansas Medical Center, Kansas City, Kansas, USA

Correspondence: Carol J Fabian, MD, University of Kansas Medical Center, 3901 Rainbow Boulevard, Kansas City, KS 66160-7320, USA.

Tel: +1913588 7791; fax: +1913588 3679; e-mail: cfabian@kumc.edu

Received: 4 December 2000

Accepted: 3 January 2001

Published: 17 January 2001
Breast Cancer Res 2001, 3:99-103

(C) 2001 BioMed Central Ltd

(Print ISSN 1465-5411; Online ISSN 1465-542X)

\begin{abstract}
A large number of new potential chemoprevention agents are available that target molecular abnormalities found in estrogen receptor (ER)-negative and/or ER-positive precancerous breast tissue and have side effect profiles that differ from tamoxifen. Classes of agents currently undergoing evaluation in clinical prevention trials or those for which testing is planned in the near future include new selective ER modulators, aromatase inactivators/inhibitors, gonadotrophin-releasing hormone agonists, monoterpenes, isoflavones, retinoids, rexinoids, vitamin D derivatives, and inhibitors of tyrosine kinase, cyclooxygenase-2, and polyamine synthesis. New clinical testing models will use morphological and molecular biomarkers to select candidates at highest short-term risk, to predict the response to a particular class of agent, and to assess the response in phase II prevention trials. If validated, morphological and molecular markers could eventually replace cancer incidence as an indicator of efficacy in future phase III trials.
\end{abstract}

Keywords: breast cancer chemoprevention, clinical models, new agents

\section{Introduction}

The demonstration by the National Surgical Adjuvant Breast and Bowel Project that tamoxifen reduces breast cancer risk by approximately $50 \%$ for at least some groups of high-risk women was a milestone in the chemoprevention of breast cancer [1]. However, other than women with a prior diagnosis of atypical hyperplasia, in situ or invasive cancer, it is not clear what groups of women receive enough benefit to offset the potential side effects. These side effects include increased risk of menstrual abnormalities and bone loss in young premenopausal women, and increased risk of hot flashes, sexual dysfunction, cataracts, uterine cancer, and thromboembolic phenomena in perimenopausal and postmenopausal women [1-3]. Concerns about the risk : benefit ratio, particularly in women over 50 , have led to the recommendation that this group not receive tamoxifen unless their short-term risk approaches $1 \%$ per year for women with a uterus and $0.5 \%$ per year for women without a uterus [4]. In the USA, many women are not given the option of simultaneous tamoxifen and hormone replacement for fear of increasing thromboembolic risk $[1,5]$. Furthermore, it is clear that the incidence of estrogen receptor (ER)-negative cancers is not reduced with preventive tamoxifen therapy and that some ER-positive precancerous lesions might be resistant to tamoxifen [1].

\section{Drug development}

Important priorities for breast cancer prevention are to develop a variety of new prevention agents that have fewer side effects or a different side effect profile from that of tamoxifen, that are compatible with hormone replacement

$\mathrm{AP}-1$ = activator protein-1; $\mathrm{COX}=$ cyclooxygenase; $\mathrm{DCIS}=$ ductal carcinoma in situ; $\mathrm{ER}=$ estrogen receptor; FNA = fine needle aspirate; HRT = hormone replacement therapy; IEN = intraepithelial neoplasia; NSABP $=$ National Surgical Adjuvant Breast and Bowel Project; RAR $=$ retinoic acid receptor; SERM = selective estrogen receptor modulator. 
therapy (HRT), and that are effective in ER-negative as well as in tamoxifen-resistant ER-positive precancerous tissue.

To develop new drugs in a short period and at reasonable cost, more efficient clinical testing models are being developed for phase I and II prevention trials. These models use potentially reversible morphological and molecular biomarkers that will enhance short-term risk prediction, that will improve the probability of response by matching the biomarker profile in precancerous tissue to agents in the appropriate drug class, and that will be used to assess response in a preliminary fashion before a cancer incidence trial [6].

\section{Biomarkers}

Several potentially reversible biomarkers have been associated with increased cancer risk, including mammographic breast density, insulin growth factor- 1 and its binding protein, serum estrogen and testosterone levels, and intraepithelial neoplasia (IEN) [7-13]. IEN is probably the risk biomarker most closely related to the underlying neoplastic process [11]. IEN can be functionally defined as a condition with morphological, molecular and genetic abnormalities as well as an increased risk for breast cancer. Using this definition, breast IEN can be viewed as beginning with simple hyperplasia and extending through atypical hyperplasia and in situ carcinoma.

Molecular alterations noted in at least a subset of IEN that clamor for targeted intervention include the following: (1) aberrant methylation and histone deacetylation of the promoter region of many tumor suppressor genes [14-16]; (2) increased growth factor and growth factor receptor expression/activation, resulting in increased mitogen-activated kinase activity; (3) increased cyclooxygenase-2 (COX-2) expression, tissue polyamines, angiogenesis and protease activity [17-21]; (4) overexpressed ER and hypersensitive ER variants [22,23]; and (5) increased aromatase and sulfatase activities, which result in increased breast estrogen levels $[24,25]$.

\section{Potential agents}

Histone deacetylase inhibitors combined with demethylating agents are promising as a means of rehabilitating silenced tumor suppressor genes in ER-negative or ERpositive precancerous tissue $[26,27]$. Inhibitors of activated tyrosine kinase, COX-2, metalloproteases, and polyamine synthesis should also have activity in ER-negative as well as ER-positive tamoxifen-resistant precancerous tissue. These types of agents might be used in premenopausal women or postmenopausal women taking HRT without altering the menstrual cycle or inducing hot flashes $[17,28]$. The same can be said of monoterpenes [29] and sulindac sulfone [30], which may act primarily to induce apoptosis [31]. Several compounds such as difluoromethylornithine (an inhibitor of polyamine synthesis) and perillyl alcohol (a monoterpene) are already in phase I-II prevention testing, and trials for others such as celecoxib, a COX-2 inhibitor, and ZD1839, a tyrosine kinase inhibitor, are in the active planning stage [32-35].

New selective estrogen receptor modulators (SERMs) that retain breast antagonist and bone agonist activity but lack uterine agonist activity might have a more attractive side effect profile than older SERMs such as tamoxifen [36]. Two new agents, EM 652 and LY 353381 (Arzoxifene), are particularly attractive in that they might be at least as efficacious as tamoxifen $[37,38]$. At present, it is unknown whether either compound will be effective in ER+ tissue which exhibits tamoxifen resistance due to ER activation and gene transcription at AP-1 sites or ligandindependent ER activation as a result of increased MAP kinase activity. [36]. Alternatively, short course treatment with pure anti-estrogens or SERMs plus tyrosine kinase inhibitors may circumvent those tamoxifen types of resistance $[36,39,40]$.

Aromatase inhibitors/inactivators act by lowering peripheral and breast tissue estrogen levels. They do not promote uterine cancer, and are associated with fewer thromboembolic phenomena than tamoxifen [41]. Drawbacks include hot flashes, lack of bone agonist effects and unknown efficacy under conditions of moderate to high circulating endogenous or exogenous estrogen levels (premenopausal women or postmenopausal women receiving HRT). However, in view of recent reports of their equal or superior efficacy in direct comparison with tamoxifen in first-line metastatic and neoadjuvant studies [41-43], prevention studies with anastrazole, letrazole and exemestane are in the active planning stage in combination with bone-preserving agents such as oral biphosphonates or calcitonin nasal spray [44].

Hormonally targeted strategies not likely to result in menstrual irregularities or hot flashes and thus likely to be more attractive to young, premenopausal women include the following: (1) soy/isoflavones, which might result in less potent levels of estrogen or estrogen metabolites [45]; (2) gonadotrophin-releasing hormone agonist regimens combined with low-dose hormone replacement [46]; and (3) short-course hormonal combinations that mimic pregnancy for nulliparous women in their late teens and early twenties [47].

Retinoids, rexinoids and vitamin $\mathrm{D}$ analogues are also undergoing active investigation in premenopausal and postmenopausal women. These compounds might be more active in ER-positive than in ER-negative precancerous tissue [48]. Retinoids and vitamin $D$ derivatives have complex mechanisms of action, which include the promotion of apoptosis through the upregulation of retinoic acid receptor (RAR) and retinoid $X$ receptor and a decrease in 
insulin growth factor levels [49-52]. In an Italian study [53], fenretinide administration resulted in a decreased incidence of contralateral breast cancer in premenopausal women with stage I breast cancer undergoing adjuvant treatment, and a phase II trial comparing fenretinide with placebo in postmenopausal women receiving HRT is nearing completion [54].

As RAR $\beta 2$ expression may be decreased in IEN through hypermethylation, retinoids have been proposed as attractive partners for demethylating agents $[27,55,56]$. Because retinoids have demonstrated efficacy in tamoxifen-resistant cell lines, retinoids, rexinoids and deltanoids might be paired with SERMs in the future $[57,58]$. Other attractive combinations of chemoprevention agents include SERMs and tyrosine kinase inhibitors or aromatase inhibitors/inactivators and COX-2 inhibitors.

\section{Dose selection}

The first hurdle to overcome in the course of the clinical evaluation of some agents is often the selection of the proper dose for prevention trials, which might be quite different than for treatment trials. In general, the dose selected for prevention trials is that associated with minimal side effects but one that nevertheless consistently modulates biomarkers consistent with its mechanism of action [59]. A popular mechanism for dose finding is the presurgical model in which a diagnostic core biopsy for ductal carcinoma in situ (DCIS) or a small invasive tumor serves as the tissue sample for baseline biomarkers. Subjects are randomized to one of several doses of drug administered in the 2 weeks between core biopsy and reexcision [6]. Because an early decrease in proliferation in neoadjuvant studies seems to correlate with clinical response to SERMs and aromatase inhibitors, the dose selected is generally that associated with a consistent decrease in proliferation $[38,42,60]$.

\section{Response evaluation}

Once a dose has been selected, how can we efficiently evaluate agents in a timely manner and at a reasonable cost? The current National Surgical Adjuvant Breast and Bowel Project Study of Tamoxifen and Raloxifene (STAR) trial with an endpoint of cancer incidence is estimated to require the enrollment of 22,000 subjects, will take 5-7 years to complete and will cost at least $\$ 200$ million. Could we use potentially reversible morphological and molecular risk biomarkers to complete prevention trials in a more expedient and less costly manner? We have demonstrated in a prospective study that hyperplasia with atypia observed in random periareolar fine needle aspirates (FNAs) from high-risk women is associated with a short-term risk of detection of DCIS or invasive cancer of 3\% per year [61]. An increase in breast cancer risk has also been noted for hyperplastic cells obtained from nipple aspirate cytology [62].
Response to a prevention agent might be evaluated in a preliminary fashion by sampling tissue before and after the drug intervention and evaluating the reversal of atypical cytological changes or the prevention of progression to hyperplasia with atypia in the treated group in comparison with a randomized control group. At the same time as breast tissue is sampled at baseline for evidence of IEN, molecular markers might be assayed to best match a subject's precancerous tissue to a particular agent (such as SERMs or aromatase inhibitors for ER-positive precancerous lesions). These strategies allow efficacy to be determined in a preliminary fashion with a fraction of the subjects, cost, and time of a cancer incidence trial. A phase II clinical trial, in which high-risk women with FNA hyperplasia with or without atypia were randomized to a polyamine synthesis inhibitor, difluoromethylornithine, or placebo for 6 months and then reaspirated, performed extremely well with consistent provision of material for analysis, excellent subject acceptance, and rapid accrual [32]. A phase II FNA study evaluating the SERM arzoxifene is ongoing.

Drugs that show promising morphological and molecular modulation in phase II trials might be moved into phase III cancer incidence trials, where they would be compared with standard prevention therapies. If the modulation of surrogate response biomarkers such as IEN can be validated as being correlated with a reduced cancer incidence in phase III trials, then prevention trials of the future might use IEN instead of cancer incidence as their main study endpoint. The concept of treatment and prevention of advanced IEN is a paradigm shift that would markedly speed prevention drug development across several disease sites; it is currently under active scrutiny by a special American Association of Cancer Research Task Force.

\section{References}

1. Fisher B, Costantino JP, Wickerham DL: Tamoxifen for prevention of breast cancer: Report of the National Surgical Adjuvant Breast and Bowel Project P-1 Study. J Natl Cancer Inst 1998, 90:1371-1388.

2. Powles TJ, Hickish T, Kanis JA, Tidy A, Ashley S: Effect of tamoxifen on bone mineral density measured by dual energy $x$-ray absorptionmetry in health premenopausal and postmenopausal women. J Clin Oncol 1996, 14:78-84.

3. Day R, Ganz PA, Costantino JP, Cronin WM, Wickerham DL, Fisher B: Health-related quality of life and tamoxifen in breast cancer prevention: a report from the National Surgical Adjuvant Breast and Bowel Project P-1.J Clin Oncol 1999, 17:2659-2669.

4. Gail MH, Costantino JP, Bryant J, Croyle R, Freedman L, Helzlsouer $\mathrm{K}$, Vogel V: Weighing the risks and benefits of tamoxifen treatment for preventing breast cancer. J Natl Cancer Inst 1999, 91:1829-1846.

5. Daly E, Vessey MP, Hawkins MM, Carson JL, Gough P, Marsh S: Risk of venous thromboembolism in use of hormone replacement therapy. Lancet 1996, 348:977-980.

6. Fabian, CJ, Kimler BF, Elledge RM: Models for early chemoprevention trials in breast cancer. Hematol Oncol Clin North America 1998, 12:993-1017.

7. Atkinson C, Warren R, Bingham SA, Day NE: Mammographic patterns as a predictive biomarker of breast cancer risk: effect of tamoxifen. Cancer Epidemiol Biomark Prev 1999, 8:863-866. 
8. Pollak M, Costantino J, Polychronakos C, Blauer SA, Guyda H, Redmond C, Fisher B, Margolese R: Effect of tamoxifen on serum insulin-like growth factor I levels in stage I breast cancer patients. J Nat/ Cancer Inst 1990, 82:1693-1697.

9. Hankinson SE, Willett WC, Colditz GA, Hunter DJ, Michaud DS, Deroo B, Rosner B, Speizer FE, Pollak M: Circulating concentrations of insulin-like growth factor-I and risk of breast cancer. Lancet 1998, 9:1393-1396.

10. Cauley JA, Lucas FL, Kuller LH, Stone K, Browner W, Cummings SR: Elevated serum estradiol and testosterone concentrations are associated with a high risk for breast cancer. Ann Intern Med 1999, 130:270-277.

11. Boone CW, Kelloff GJ: Intraepithelial neoplasia, surrogate endpoint biomarkers, and cancer chemoprevention. J Cell Biochem 1993, 17(suppl):37-48.

12. Tavassoli FA: Mammary intraepithelial neoplasia: a translational classification system for the intraductal epithelial proliferations. Breast J 1997, 3:48-58.

13. Page DL, Rogers LW: Combined histologic and cytologic criteria for the diagnosis of mammary atypical ductal hyperplasia. Hum Pathol 1992, 23:1095-1097.

14. Cameron EE, Bachman KE, Myohanen S, Herman JG, Baylin SB: Synergy of demethylation of histone deacetylase inhibition in the re-expression of genes silenced in cancer. Nature 1999, 21:103-107.

15. Marks PA, Richon JM, Rifkind RA: Histone deacetylase inhibitors: inducers of differentiation of apoptosis of transformed cells. J Nat/ Cancer Inst 2000, 92:1210-1216.

16. Nass SJ, Herman JG, Gabrielson E: Aberrant methylation of the estrogen receptor and $\mathrm{E}$-cadherin $5^{\prime} \mathrm{CpG}$ islands increases with malignant progression in human breast cancer. Cancer Res 2000, 60:4346-4348.

17. Koki AT, Leahy KM, Masferrer JL: Potential utility of COX-2 inhibitors in chemoprevention and chemotherapy. Exp Opin Invest Drugs 1999, 8:1623-1638.

18. Roger $\mathrm{P}$, Daures JP, Maudelonde T, Pignodel C, Gleizes M, Chapelle J, Marty-Double C, Baldet P, Mares P, Laffargue F, Rochefort H: Dissociated overexpression of cathepsin D and estrogen receptor $\alpha$ in preinvasive mammary tumors. Hum Pathol 2000, 31:593-600.

19. Nelson AR, Fingleton B, Rothenberg ML, Matrisian LM: Matrix metalloproteinases: biologic activity and clinical implications. $J$ Clin Oncol 2000, 18:1135-1149.

20. Leveque J, Foucher F, Havouis R, Desury D, Grall JY, Moulinoux JP: Benefits of complete polyamine deprivation in hormone responsive and hormone resistant MCF-7 human breast adenocarcinoma in vivo. Anticancer Res 2000, 20:97-101.

21. Fregene TA, Kellogg CM, Pienta KJ: Microvessel quantification as a measure of angiogenic activity in benign breast tissue lesions: a marker for precancerous disease? Int J Oncol 1994, 4:1999-2002.

22. Khan SA, Rogers MA, Obando JA, Tamsen A: Estrogen receptor expression of benign breast epithelium and its association with breast cancer. Cancer Res 1994, 54:993-997.

23. Fuqua SA, Wiltschke C, Zhang QX, Borg A, Castles CG, Friedrichs WE, Hopp T, Hilsenbeck S, Mohsin S, O'Connell $P$, Allred DC: $A$ hypersensitive estrogen receptor- $\alpha$ mutation in premalignant breast lesions. Cancer Res 2000, 60:40264029.

24. Santen RJ, Martel J, Hoagland M, Naftolin F, Roa L, Harada N, Hafer L, Zaino R, Pauley R, Santner S: Demonstration of aromatase activity and its regulation in breast tumor and benign breast fibroblasts. Breast Cancer Res Treat 1998, 49:S93-S99.

25. Pasqualini JR: Recent developments of the biological role of progestins in human breast cancer. J Women's Cancer 2000, 2:135-143

26. Ferguson AT, Lapidus RG, Baylin SB, Davidson NE: Demethylation of the estrogen receptor gene in estrogen receptor- negative breast cancer cells can reactivate estrogen receptor gene expression. Cancer Res 1995, 55:2279-2283.

27. Sporn MB: Retinoids and demethylating agents - looking for partners. J Natl Cancer Inst 2000, 92:780-781.

28. Duffy, M.J., Maguire TM, Hill A, McDermott E, O'Higgins N: Metalloproteinases: role in breast carcinogenesis, invasion and metastasis. Breast Cancer Res 2000, 2:252-257.

29. Gould MN: Prevention and therapy of mammary cancer by monoterpenes. J Cell Biochem Supp/ 1995, 22:139-144.
30. Thompson HJ, Jiang C, Lu J, Mehta RG, Piazza GA, Paranka NS Pamukcu R, Ahnen DJ: Sulfone metabolite of sulindac inhibits mammary carcinogenesis. Cancer Res 1997, 57:267-271.

31. Ariazi EA, Satomi Y, Ellis MJ, Haag JD, Shi W, Sattler CA, Gould $\mathrm{MN}$ : Activation of the transforming growth factor $\beta$ signaling pathway and induction of cytostasis and apoptosis in mammary carcinomas treated with the anticancer agent perilIyl alcohol. Cancer Res 1999, 59:1917-1928.

32. Fabian CJ, Kimler BF, Brady D, Zalles CM, Mayo MS, Masood S, Grizzle WE: Phase II chemoprevention trial of DFMO using the random FNA model. In 23rd Annual San Antonio Breast Cancer Symposium, December 6-9, 2000, San Antonio, Texas.

33. Chan KC, Knox WF, Woodburn JR, Potten CS, Bundred NJ: 1999. ZD1839 (Iressa ${ }^{\mathrm{T} M}$ ) an epidermal growth factor receptor (EGFR) tyrosine kinase inhibitor, inhibits proliferation in normal and preinvasive breast epithelia [abstract]. Clin Cancer Res 1999, 5 (suppl):3735s.

34. Ripple GH, Gould MN, Stewart JA, Tutsch KD, Arzoomanian RZ, Alberti D, Feierabend C, Pomplun M, Wilding G, Bailey $H H$ : Phase I clinical trial of perillyl alcohol administered daily. Clin Cancer Res 1998, 4:1159-1164.

35. Harris RE, Alshafie GA, Abou-Issa H, Seibert K: Chemoprevention of breast cancer in rats by celecoxib, a cyclooxygenase 2 inhibitor. Cancer Res 2000, 60:2101-2103.

36. Osborne CK, Zhao H, Fugua SAW: Selective estrogen receptor modulators: structure, function and clinical use. J Clin Oncol 2000, 18:3172-3186.

37. Llombart-Cussac, Bellet AM, Guillem-Porta V, Petruzelka L, Enas N, Chick J, Dhingra K, Storniolo A, Baselga J: Efficacy and safety of two doses of the selective estrogen receptor modulator (Serm) Ly353381 in locally advanced or metastatic breast cancer (LAMBC): a randomized double blind phase 2 study [abstract]. Proc Am Soc Clin Oncol 2000, 19:157a.

38. Fabian CJ, Kimler BF, Anderson J, Tawfik O, Mayo MS, O'Shaughnessy JA, Albain, KA, Burak WE, Jr., Ihde JK, Ganz PA, Budd GT, Lawrence JA: Phase I biomarker and toxicity evaluation of LY353381 (a 3rd generation selective estrogen receptor modulator, SERM) in breast cancer [abstract]. Proc Am Soc Clin Oncol 2000, 19:75a.

39. Robertson JFR, Dixon M, Bundred N, Anderson E, Dowsett N, Nicholson R, Ellis I: A partially-blind, randomised, multicentre study comparing the anti-tumor effects of single doses (50, 125 , and $250 \mathrm{mg}$ ) of long-acting (LA) 'faslodex' (ICI 182,780) with tamoxifen in postmenopausal women with primary breast cancer prior to surgery [abstract]. Breast Cancer Res Treat 1999, 57:31.

40. Kato $S$, Endoh $H$, Masuhiro $Y$, Kitamoto $T$, Uchiyama $S$, Sasaki $H$, Masushige S, Gotoh Y, Nishida E, Kawashima H, Metzger D, Chambon P: Activation of the estrogen receptor through phosphorylation by mitogen-activated protein kinase. Science 1995, 270:1491-1494

41. Nabholtz JM, Buzdar A, Pollak M, Harwin W, Burton G, Mangalik A, Steinberg M, Webster A, von Euler M: Anastrozole is superior to tamoxifen as first-line therapy for advanced breast cancer in postmenopausal women: results of a North American multicenter randomized trial. J Clin Oncol 2000, 18:3758-3767.

42. Dixon JM, Love CD, Renshaw L, Bellamy C, Cameron DA, Miller WR, Leonard RC: Lessons from the use of aromatase inhibitors in the neoadjuvant setting [review]. EndocrineRelated Cancer 1999, 6:227-230.

43. Buzdar, A., Nabholtz JM, Robertson JF, Thurlimann B, Bonneterre J, von Euler M, Steinberg M, Webster A: Anastrozole (arimidex) versus tamoxifen as first-line therapy for advanced breast cancer $(\mathrm{Abc})$ in postmenopausal $(\mathrm{Pm})$ women - combined analysis from two identically designed multicenter trials [abstract]. Proc Am Soc Clin Oncol 2000, 19:154a

44. Harper-Wynne CL, Ross GM, Sacks NP, Gui GP, Dowsett M: Study of the biological effects of the aromatase inhibitor letrazole in healthy postmenopausal women: rationale for prevention [abstract]. Breast Cancer Res Treat 2000, 64:47.

45. Xu X, Duncan AM, Merz BE, Kurzer MS: Effects of soy isoflavones on estrogen and photoestrogen metabolism in premenopausal women. Cancer Epidemiol Biomark Prev 1998, 7:1101-1108.

46. Spicer DV, Pike MC: Future possibilities in the prevention of breast cancer: Luteinizing hormone-releasing hormone agonists. Breast Cancer Res 2000, 2:264-267. 
47. Guzman RC, Yang J, Rajkumar L, Thordarson G, Chen X, Nandi $\mathrm{S}$ : Hormonal prevention of breast cancer: mimicking the protective effect of pregnancy. Proc Natl Acad Sci USA 1999, 96:2520-2525.

48. van der Leede BJ, Folkers GE, van den Brink CE, van der Saag PT, van der Burg B: Retinoic acid receptor $\alpha 1$ isoform is induced by estradiol and confers retinoic acid sensitivity in human breast cancer cells. Mol Cell Endocrinol 1995, 109:77-86.

49. Liu Y, Lee MO, Wang HG, Li Y, Hashimoto Y, Klaus M, Reed JC, Zhang $X$ : Retinoic acid receptor $\beta$ mediates the growthinhibitory effect of retinoic acid by promoting apoptosis in human breast cancer cells. Mol Cell Biol 1996, 16:1138-1149.

50. Swami S, Krishnan AV, Feldman D: 1 $\alpha$, 25-dihydroxy-vitamin D3 down regulates estrogen receptor abundance and suppresses estrogen actions in MCF-7 human breast cancer cells. Clin Cancer Res 2000, 6:3371-3379.

51. Vink-van Wijngaarden T, Pols HA, Buurman CJ, Birkenhager JC, van Leeuwen JP: Inhibition of insulin and insulin-like growth factor-1-stimulated growth of human breast cancer cells by 1,25 dihydroxyvitamin D3 and the vitamin D3 analogue EB 1089. Eur J Cancer 1996, 32A:842-848.

52. Mehta R, Hawthorne M, Uselding L, Albinescu D, Moriarty R, Christov K, Mehta R: Prevention of $\mathrm{N}$-methyl- $\mathrm{N}$-nitrosoureainduced mammary carcinogenesis in rats by $1 \alpha$-hydroxyvitamin $D_{5}$. J Nat/ Cancer Inst 2000, 92:1836-1840.

53. Veronesi U, De Palo G, Marubini E, Costa A, Formelli F, Mariani L, Decensi A, Camerini T, Del Turco MR, Di Mauro MG, Muraca MG, Del Vecchio M, Pinto C, D'Aiuto G, Boni C, Campa T, Magni A, Miceli R, Perloff M, Malone WF, Sporn MB: Randomized trial of fenretinide to prevent second breast malignancy in women with early breast cancer. I Natl Cancer Inst 1999, 91: $1847-1856$

54. Bonanni B, Ramazzotto F, Fanchi D, Buttarelli M, Valente I, Stegher C, Daldoss C, Pigatto F, Mora S, Cazzaniga M, Pizzamiglio M, Pelosi G, Decensi A: A randomized trial of fenretinide in HRT users using IGF-1 as a surrogate biomarker [abstract]. Breast Cancer Res Treat 2000, 64:48.

55. Xu XC, Xneige N, Liu X et al: Progressive decrease in nuclear retinoic acid receptor $\beta$ messenger RNA level during breast carcinogenesis. Cancer Res 1997, 57:4992-4996.

56. Widschwendter M, Berger J, Hermann M, Muller HM, Amberger A, Zeschnigk M, Widschwendter A, Abendstein B, Zeimet AG, Daxenbichler G, Marth C: Methylation and silencing of the retinoic acid receptor-B2 gene in breast cancer. J Nat/ Cancer Inst 2000, 92:826-832.

57. Bischoff ED, Gottardis MM, Moon TE, Heyman RA, Lamph WW: Beyond tamoxifen: the retinoid $X$ receptor-selective ligand LGD1069 (TARGRETIN) cause complete regression of mammary carcinoma. Cancer Res 1998, 58:479-484.

58. Brown PH, Lippman SM: Chemoprevention of breast cancer. Breast Cancer Res Treat 2000, 62:1-17.

59. Kelloff GJ, Boone CW, Steele VE, Crowell JA, Lubet R, Sigman CC: Progress in cancer chemoprevention: perspectives on agent selection and short-term clinical intervention trials. Cancer Res 1994, 54(suppl):2015S-2024S.

60. Dowsett M, Dixon JM, Horgan K, Salter J, Hills M, Harvey E: Antiproliferative effects of Idoxifene in a placebo-controlled trial in primary human breast cancer. Clin Cancer Res 2000, 6:2260-2267.

61. Fabian CJ, Kimler BF, Zalles CM, Klemp JR, Kamel S, Zeiger S, Mayo MS: Short-term breast cancer prediction by random periareolar fine-needle aspiration cytology and the Gail risk model. J Natl Cancer Inst 2000, 92:1217-1227.

62. Wrensch M, Petrakis NL, King EB, Lee MM, Miike R: Breast cancer risk associated with abnormal cytology in nipple aspirates of breast fluid and prior history of breast biopsy. Am J Epidemiol 1993, 137:829-833. 